
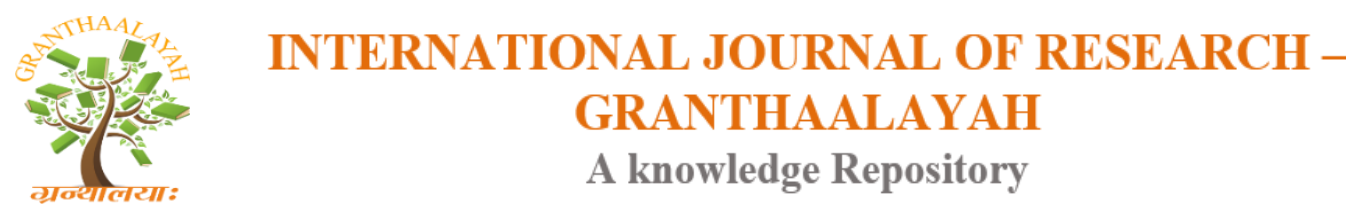

Science

\title{
ASSESSMENT OF HEAVY METAL CONCENTRATIONS IN GROUND WATER IN CRITICAL AREAS OF VISAKHAPATNAM CITY, AP, INDIA
}

\author{
M. Sudhakar Reddy ${ }^{1}$, T. Byragi Reddy ${ }^{2}$, CH. Venkataramana ${ }^{3}$ \\ $1,{ }^{* 3}$ Research Scholar, Department of Environmental Sciences, Andhra University, \\ Visakhapatnam, India \\ ${ }^{2}$ Professor, Department of Environmental Sciences, Andhra University, Visakhapatnam, India
}

\begin{abstract}
Presence of heavy metal concentration in the ground water may cause health problems during intake of through different ways. Present study focused on heavy metal concentration of ground water in the sub-urban areas of Visakhapatnam City, AP, India. Most of heavy metals i.e., Aluminum (Al), Chromium (Cr), Manganese (Mn), Iron (Fe), Nickel (Ni), Zinc (Zn), Arsenic (As), Cadmium $(\mathrm{Cd})$, Mercury $(\mathrm{Hg})$ and Lead $(\mathrm{Pb})$ were analyzed using Inductive Coupled Plasma Mass Spectroscopy (ICP-MS). Mean values of $\mathrm{Zn}(1.845)>\mathrm{Mn}(1.203)>\mathrm{Fe}(0.664)>\mathrm{Al}(0.334)>\mathrm{Pb}$ $(0.245)>\mathrm{Ni}(0.082)>\mathrm{Cr}(0.066)>\mathrm{As}(0.028)>\mathrm{Cd}(0.012)>\mathrm{Hg}(0.010)$ results respectively. Results shows that all heavy metal concentrations were exceeded the water quality permissible limit and this area were not suitable for domestic purpose and use before proper treatment.
\end{abstract}

Keywords: Heavy Metal; Ground Water; Sub-urban Areas.

Cite This Article: M. Sudhakar Reddy, T. Byragi Reddy, and CH. Venkataramana. (2018). "ASSESSMENT OF HEAVY METAL CONCENTRATIONS IN GROUND WATER IN CRITICAL AREAS OF VISAKHAPATNAM CITY, AP, INDIA." International Journal of Research - Granthaalayah, 6(9), 239-245. https://doi.org/10.5281/zenodo.1442425.

\section{Introduction}

Ground water is the major source of drinking water in both urban and rural areas (Saravanakumar and Ranjith Kumar, 2011). It is the most importantsource of water supply for drinking and irrigation purposes in rural areas. Ground water quality plays animportant role in groundwater protection and quality conservation. Hence it is very important to assess theground water quality not only for its present use but also from the view point of a potential source of water forfuture consumption (Kori et al., 2006). Water sources available for drinking and other domestic purpose must possess highdegree of purity, free from chemical contamination and micro-organism (Borul and Banmeru, 2012). The people of Visakhapatnam useswell, bore wells and municipal water for their daily activities and also for drinking purposes. Water resources arepoorly managed in rural areas. The good quality water supply to such citizens is basic need. Agriculturalwaste, domestic and community solid liquid waste further deteriorate the ground water quality. 


\section{Materials and Methods}

\section{Study Area}

The present study area (fig.1) the Visakhapatnam city region comprises of Precambrian metasediments and intrusive meta igneous bodies (Narasimha Rao, 1945). The hill ranges named Kailasa on north, Yarada on south, Narava on west made the city to appear like a amphitheater. These entire hill ranges are composed of granite- sillmanite- biotitegeneises locally called as Khondolites (King, 1886), charnockites, leptynites.

The study area is located between latitude- $17^{\circ} 30^{\prime} 15^{\prime \prime}$ to $18^{\circ} 11^{\prime} 15^{\prime \prime}$ North and longitude- $82^{\circ} 57^{\prime} 37^{\prime \prime}$ to $83^{\circ} 28^{\prime} 12^{\prime \prime}$ East. Visakhapatnam has been notified as one of the most polluted industrial cluster by central pollution control board of India. The study area experiences a semi-arid climate, with temperature in the range of $15-38^{\circ} \mathrm{C}$. The annual average rainfall is $1080 \mathrm{~mm}$. The sub-surface geology indicates that the average weathered rock portion extends up to $16 \mathrm{~m}$ and the fractured rock zone up to $30 \mathrm{~m}$ depth from the ground surface. The red sediments vary in depth from 1 to $3 \mathrm{~m}$, with an average of about $2 \mathrm{~m}$, from surface level, depending upon the topography.

Rainfall is the main natural replenishable recharge source of groundwater. The depth to groundwater level ranges from 2 to $11 \mathrm{~m}$ Below Ground Level (BGL). Shallow groundwater level less than 3m BGL was observed at topographic-lows (downstream), while deep groundwater level more than 9m BGL was found at elevated ground (upstream; Figure 1). The general slope of the area was towards the salt marsh land from all the directions. Hence, the direction of the groundwater flow followed the topography of the area.

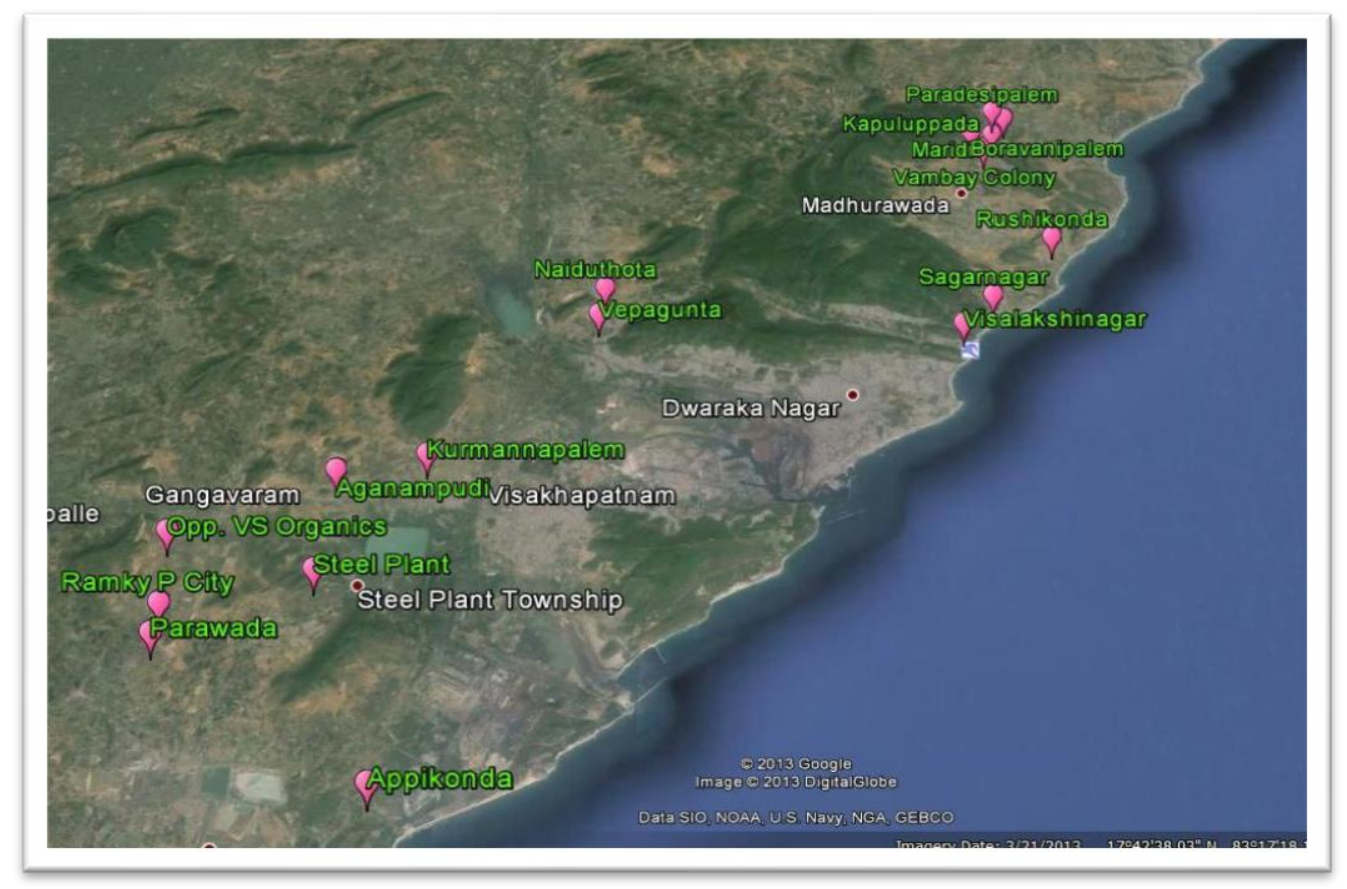

Figure 1: Showing sampling locations (Study Area)

Water samples were drawn from bore wells, hand pumps and Visakhapatnam during monsoon period. Samples were collected during months of mid-June to Mid-September, 2017 from the selected sites. Borosilicate glass wares, distilled water and standard reagents were used throughout the analysis. The study includes collection of data on pollution backdrop of the area and collection 
of ground water samples during summer season of 2016. Twenty five tube well water samples were collected covering the southern industrial part of the study area for the subsequent laboratory analysis, for heavy metals like such as aluminium $(\mathrm{Al})$, chromium $(\mathrm{Cr})$, manganese $(\mathrm{Mn})$, nickel $(\mathrm{Ni})$,zinc $(\mathrm{Zn})$, arsenic $(\mathrm{As})$, cadmium $(\mathrm{Cd})$,mercury $(\mathrm{Hg})$, and lead $(\mathrm{Pb})$ Using suprapure®nitric acid, MIBK and APDC analytical grade chemicals the solvent extraction procedure was performed in the pollution testing laboratory in school of environmental sciences, Andhra university, all the sample extracts were subjected to ICPMS analysis at center for studies on Bay of Bengal, Andhra University.

\section{Results and Discussions}

\section{Results}

Table 1: Ground Water Heavy Metal Analysis results (ICP-MS)

\begin{tabular}{|c|c|c|c|c|c|c|c|c|c|c|c|}
\hline \multicolumn{2}{|l|}{ Location } & Al & $\mathrm{Cr}$ & Mn & $\mathbf{F e}$ & $\mathrm{Ni}$ & $\mathbf{Z n}$ & As & Cd & $\mathrm{Hg}$ & $\mathbf{P b}$ \\
\hline \multicolumn{2}{|l|}{ Op VS organics } & 0.327 & 0.004 & 0.032 & 0.244 & 0.021 & 0.505 & 0.005 & 0.014 & 0.004 & 0.366 \\
\hline \multicolumn{2}{|l|}{ RamkyPcity } & 0.471 & 0.004 & 0.254 & 0.362 & 0.025 & 0.46 & 0.002 & 0.001 & 0.006 & 0.064 \\
\hline \multicolumn{2}{|l|}{ Appikonda } & 0.23 & 0.013 & 0.149 & 0.317 & 0.017 & 1.263 & 0.005 & 0.001 & 0.002 & 0.043 \\
\hline \multicolumn{2}{|l|}{ Steel Plant } & 0.245 & 0.153 & 6.452 & 2.86 & 0.115 & 7.807 & 0.051 & 0.003 & 0.004 & 0.802 \\
\hline \multicolumn{2}{|l|}{ Aganampudi } & 0.105 & 0.004 & 0.007 & 0.195 & 0.066 & 0.046 & 0.001 & 0.000 & 0.004 & 0.051 \\
\hline \multicolumn{2}{|l|}{ Kurmanapalem } & 0.25 & 0.077 & 3.565 & 1.229 & 0.077 & 5.308 & 0.019 & 0.001 & 0.003 & 0.048 \\
\hline \multicolumn{2}{|l|}{ Naiduthota } & 0.26 & 0.011 & 0.097 & 0.323 & 0.03 & 1.707 & 0.007 & 0.007 & 0.016 & 0.515 \\
\hline \multicolumn{2}{|l|}{ Vepagunta } & 0.18 & 0.003 & 0.014 & 0.197 & 0.034 & 0.257 & 0.024 & 0.001 & 0.016 & 0.04 \\
\hline \multicolumn{2}{|l|}{ Visalakshinagar } & 0.301 & 0.009 & 0.011 & 0.072 & 0.029 & 0.258 & 0.005 & 0.001 & 0.022 & 0.024 \\
\hline \multicolumn{2}{|l|}{ Sagarnagar } & 0.155 & 0.016 & 0.009 & 0.268 & 0.096 & 1.341 & 0.107 & 0.003 & 0.006 & 0.136 \\
\hline \multicolumn{2}{|l|}{ Rushikonda } & 0.344 & 0.111 & 6.397 & 1.243 & 0.077 & 6.918 & 0.006 & 0.002 & 0.002 & 0.032 \\
\hline \multicolumn{2}{|l|}{ BoravaniPalem } & 0.838 & 0.385 & 0.313 & 0.451 & 0.175 & 0.571 & 0.069 & 0.006 & 0.047 & 0.918 \\
\hline \multicolumn{2}{|l|}{ Kapuluppada } & 0.383 & 0.07 & 0.185 & 0.234 & 0.154 & 0.398 & 0.045 & 0.133 & 0.008 & 0.294 \\
\hline \multicolumn{2}{|l|}{ Paradesipalem } & 0.957 & 0.074 & 0.176 & 0.928 & 0.166 & 0.482 & 0.088 & 0.008 & 0.009 & 0.698 \\
\hline \multicolumn{2}{|l|}{ Maridi } & 0.25 & 0.115 & 0.087 & 0.136 & 0.1 & 0.672 & 0.01 & 0.022 & 0.008 & 0.139 \\
\hline \multicolumn{2}{|l|}{ Vambay colony } & 0.12 & 0.015 & 0.014 & 0.573 & 0.12 & 0.87 & 0.022 & 0.002 & 0.004 & 0.111 \\
\hline \multicolumn{2}{|l|}{ Min } & 0.105 & 0.003 & 0.007 & 0.072 & 0.017 & 0.046 & 0.001 & 0.000 & 0.002 & 0.024 \\
\hline \multicolumn{2}{|l|}{ Max. } & 0.957 & 0.385 & 6.452 & 2.86 & 0.175 & 7.807 & 0.107 & 0.133 & 0.047 & 0.918 \\
\hline \multicolumn{2}{|l|}{ Average } & 0.334 & 0.066 & 1.203 & 0.644 & 0.082 & 1.845 & 0.028 & 0.012 & 0.010 & 0.254 \\
\hline \multirow{2}{*}{$\begin{array}{l}\text { Standards IS } \\
10500 \mathrm{ppm}\end{array}$} & Dest & 0.03 & 0.05 & 0.1 & 0.3 & 0.02 & 5.0 & 0.05 & 0.01 & 0.001 & 0.05 \\
\hline & Permissible & 0.2 & NR & 0.3 & 1.0 & NR & 15 & NR & NR & NR & NR \\
\hline
\end{tabular}

(Note: All values are expressed in ppm, NR: No Relaxation)

In the present study, the concentration of aluminum is ranges from $0.105-0.957 \mathrm{ppm}$ with mean of $0.334 \mathrm{ppm}$ (shown in table. 1). Maximum value recorded at Paradesipalem (0.957ppm) while minimum values were recorded at Aganampudi $(0.105 \mathrm{ppm})$. About half of the samples exceeded the permissible level of $0.2 \mathrm{ppm}$ (BIS) the results indicated that there was an environmental impact on the ground water of these areas due to industrialization and solid waste dumping where the values were higher. Aluminium salts generally form complexes with phosphate and are excreted in the faeces (Thienes and Haley, 1972).

In the present study, the concentration of chromium is ranges from $0.003-0.385$ ppm with mean of $0.066 \mathrm{ppm}$ (shown in table.1). Maximum value at Boravanipalem $(0.385 \mathrm{ppm}$ ) while minimum at Vepagunta $(0.003 \mathrm{ppm})$ but Maximum contamination level ofchromium in ground water is 
$0.05 \mathrm{ppm} / \mathrm{L}$ according to BIS. Because of the low solubility of chromium, generally the levels found in water are usually low $(<5 \mu \mathrm{g} / \mathrm{L})$. There is a wide variation in the $\mathrm{Cr}$ (VI) contents in groundwater samples throughout the study area and the toxicity is depends on its physico-chemical shape; hexavalent salts are considered the most dangerous (Lauwerys, 1992).

The concentration of manganese is ranges from $0.007-6.452 \mathrm{ppm}$ with mean of $1.203 \mathrm{ppm}$ (shown in table.1). Maximum value at Steel Plant (6.452) while lowest concentration recorded at Aganampudi $(0.007 \mathrm{ppm})$ but maximum acceptable limit and maximum contamination level (MCL) (BIS) were $0.1 \mathrm{ppm} / \mathrm{L}$ and $0.3 \mathrm{ppm} / \mathrm{L}$ of manganese in ground water. Most of the samples were exceeded the MCL $(0.3 \mathrm{ppm})$ (BIS). The general range of manganese in natural waters is 0.005 to $1 \mathrm{mg} / \mathrm{L}$ (WHO, 2004). Only one case of manganese intoxication has been reported in Japan in which the cause of encephalitis like disease was attributed to the presence of $14 \mathrm{mg} / \mathrm{L}$ of Manganese in the well water.

In the present study, the concentration of iron ranges from $0.072-2.860 \mathrm{ppm}$ with mean of 0.644 ppm (shown in table.1). Maximum value at Steel Plant $(2.860 \mathrm{ppm})$ while lowest concentration was recorded at Visalakshinagar $(0.072 \mathrm{ppm})$. Maximum acceptable limit and maximum contamination level (MCL) are $0.1 \mathrm{ppm} / \mathrm{L}$ and $0.3 \mathrm{ppm} / \mathrm{L}$ of Iron in ground water. Most of the samples exceeded the maximum contamination level of iron of $0.3 \mathrm{ppm} / \mathrm{L}$ (BIS, 2006). Concentration of iron above $1.00 \mathrm{mg} / \mathrm{l}$ of iron in drinking water is not considered to be suitable for drinking purposes. About $98 \%$ of the water samples contain iron above $0.3 \mathrm{mg} / \mathrm{l}$, the concentration above which the water taste is usually unacceptable (WHO, 2004). In general; iron is a common element in arsenic-contaminated waters (Welch et al., 2000; Chakraborti et al., 2001; Williams, 2001; Meng et al., 2001).

In the present study, the concentration of nickel ranges from $0.017-0.175 \mathrm{ppm}$ with mean of $0.082 \mathrm{ppm}$ (shown in table.1). All the ground water samples exceeded the maximum permissible level of $0.02 \mathrm{ppm} / \mathrm{L}$ (BIS, 1991). Maximum concentrations were recorded at Boravanipalem $(0.175 \mathrm{ppm})$ while lowest concentration was recorded at Appikonda (0.017ppm). Nickel concentrations in the groundwater depend on the soil use, $\mathrm{pH}$, and depth of sampling (WHO, 2005). Nickel was also found to be responsible for many sexual disorders (Chakroun et al., 2002). Zinc is present in the drinking water, surface and ground waters in the range of 0.01 to $1 \mathrm{mg} / \mathrm{L}$. In the present study, the concentration of zinc ranges from $0.046-7.807 \mathrm{ppm}$ with mean of 1.845 ppm (shown in table. 1). The maximum concentrations of zinc were recorded at Steel Plant (7.807ppm) while lowest concentrations were recorded at Aganampudi (0.046ppm). The prescribed concentrations for Zinc are between $0.09-0.43 \mathrm{mg} / \mathrm{L}$ and $5.0 \mathrm{mg} / \mathrm{L}$ according to BIS and World Health Organization (WHO) respectively. Tap water may contain higher concentration due to leaching from the pipes (Legittimo et al., 1985; Alam and Sadiq Muhammad, 1989; Schock and Neff, 1988).

Arsenic is the 20th most abundant element found naturally in the Earth's crust. In the present study, the concentration of arsenic ranged from $0.001-0.107 \mathrm{ppm}$ with mean of $0.028 \mathrm{ppm}$ (shown in table.1). Maximum concentrations of arsenic were recorded at Sagarnagar (0.107ppm) while lowest concentrations recorded at Aganampudi $(0.001 \mathrm{ppm})$. The maximum acceptable level of arsenic is 0.05ppm (BIS, 1991). Several other studies reported that chronic intakes of about 10 $\mu \mathrm{g} / \mathrm{kg}$ body $\mathrm{wt} /$ day or higher values may result in dermatological and other signs of arsenic toxicity 
(Hindmarsh et al., 1977; Cerbrian et al., 1983; Chakraborty and Saha, 1987; Abernathy et al., 1989; Roychowdhury et al., 2002b; Rahman et al., 2003; Roy chowdhury, 2008a).

Cadmium is usually present in all soils and rocks. In the present study, the concentration of cadmium ranges from $0.00-0.133 \mathrm{ppm}$ with mean of $0.012 \mathrm{ppm}$ (shown in table.1). Maximum concentrations of cadmium were recorded at Kapuluppadda $(0.133 \mathrm{ppm})$ while lowest concentrations recorded at Aganampudi (0.00ppm) and acceptable level is 0.003ppm (BIS, 1991). Chronic exposure to low doses of cadmium causes damage to the renal tubules, followed by proteinuria, pulmonary lesions and arterial hypertension (Bertouille, 1978).

In the present study, the concentration of mercury ranges from $0.002-0.047 \mathrm{ppm}$ with mean of $0.010 \mathrm{ppm}$ (shown in table.1). Maximum concentrations of mercury were recorded at Boravanipalem $(0.047 \mathrm{ppm})$ while lowest concentrations were recorded at Appikonda and Rushikonda (0.002ppm). Acceptable level of mercury is $0.001 \mathrm{ppm}$ (BIS, 1991). Mercury, toxicity results in mental disturbance and impairment of speech, hearing, vision and movement (Hammer and Hammer Jr., 2004). Chronic mercury poisoning results from exposure to small amounts of mercury over extended time period. Dramatic instances of toxicosis in human beings occurred in Japan (the Minamata disease), Iraq, Pakistan and Guatemala (D'Itri and D'Itri, 1977). Humic substances also may play a role in reducing ionic mercury to the elemental form in aqueous systems (Allard and Arsenie, 1991).

Lead pipes also contribute dissolved lead to the water flowing through them (Lopez desa, 1989; Murrell, 1985; Wagner 1987). In the present study, the concentration of lead ranged from $0.024-$ $0.918 \mathrm{ppm}$ with mean of $0.254 \mathrm{ppm}$ (shown in table.1). Maximum concentrations of lead were recorded atBoravanipalem $(0.918 \mathrm{ppm})$ while lowest concentrations were recorded at Visalakshinagar (0.024ppm). The maximum acceptable level of lead is 0.001ppm(BIS, 1991). Lead also passes the blood brain barrier, although the brain does not accumulate lead (WHO 1980).

\section{Conclusions and Recommendations}

As the demand for water is increasing rapidly with the resources staying the same there is a huge rift in the demand-supply dynamics of water. As the surface water resources are becoming scarcer we are relying more and more on groundwater to meet our ever-increasing needs. The prominence and importance of water as an asset has been growing rapidly and the proper management of water is the most important necessity now. Drinking water standards with respect to heavy metals revealed that the Aluminum $(\mathrm{Al})$ concentrations were high in all the sampling locations except Paradesipalem. The results indicate that there is an environmental impact on the ground water of these areas due to industrialization and solid waste dumping where the values were higher. Chromium concentrations were high only in Mindi followed by Boravanipalem, Steel Plant, Maridi, Rusikonda, Sriharipuram, Kurmannapalem and Paravada while remaining sampling locations indicated $\mathrm{Cr}$ within the permissible limit of drinking water standards.

Manganese concentrations similarly showed excess in Mindi, Steel Plant, Rusikonda, Sriharipuram, Kurmannapalem, Parawada and Pandurangapuram while remaining sampling locations indicated permissible limit. Iron concentrations were highest in Mindi followed by 
Akkireddypalem, Peddagantyada, Sriharipuram, Pandurangapuram, Parawada, Rusikonda, Paradesipalem, Dabagardens, Sheelanagar, Gnanapuram, Dwarakanagar and Vambay Colony.

Compared with ground water standards the nickel concentrations were very low except in Mindi, NAD Junction, Boravanipalem, Paradesipalem, Kapuluppada Village, Steel Plant, Maridi, Dabagardens and Parawada. Copper concentrations were highest at Sagarnagar Kapuluppada Village Boravanipalem Mindi Maridi Steel Plant, Vambay Colony, Sriharipuram, Peddagantyada, Kurmannapalem, Paradesipalem, NAD Juction, Visalakshinagar, Parawada, Akkireddypalem, Dabagardens, Naiduthota, Pandurangapuram and Lawsons Bay Colony.

The above results relating to heavy metal pollution follow a definite trend with reference to industrialization. The pollution was more in highly industrial areas decreasing in residential areas. The focus of remediation should be in those industrial areas where most of the industrial workers reside with inadequate sanitation and infrastructure. Water treatment plants should be provided in these areas immediately.

\section{References}

[1] Abernathy, C.O., Marcus, W., Chen, C., Gibb, H., Write, P., (1989); Report on Arsenic Work Group Meeting, Office of Drinking Water, Office of Research and Development, USEPA, Memorandum to P. Cork, P. Press. Office of Regulatory Supportand Scientific Management, USEPA.

[2] Allard, B., Arsenie, I., (1991); Abiotic reduction of mercury by humic substances in aquatic systeman important process for the mercury cycle. Water, Air, Soil Pollut. 56, 457 - 464.

[3] Bertouille, S. (1978); Fertility of red deer in relation to area, age, body mass, and mandible length, Springer Berlin, 87 - 98.

[4] BIS Tolerance limits for Inland surface water IS: 2296-1982 and BIS standard 2006.

[5] Borul S. B. and Banmeru P. K., (2012); "Physiochemical analysis of ground water for drinking from 1selected sample points around the Manmeru Science College, Lonar Buldana district of Maharashtra", Journal of Chemical and Pharmaceutical Research, 4(5): 2603-2606.

[6] Cerbrian, M.E., Albores, A., Aquilar, M., Blakely, E., (1983); Chronic arsenic poisoning in the north of Mexico. Human Toxicol. 2, 121-133.

[7] Chakraborti, D., Basu, G.K., Biswas, B.K., Chowdhury, U.K., Rahman, M.M., Paul, K., Roychowdhury, T., Chanda, C.R., Lodh, D., Ray, S.L., (2001); Characterization of arsenic-bearing sediments in the Gangetic delta of West Bengal, India. In:

[8] Chakraborty, A.K., Saha, K.C., (1987); Arsenical dermatosis from tubewell water in West Bengal. Ind. J. Med. Res. 85, 326-334.

[9] Chakroun, H., Hfaidh, N., Makni-Ayadi, F., Guermazi, F., Kammoun, A. and Elfeki, A., (2002); Nickel and fertility in the rat. Sexologies, 12: 1-4.

[10] D'Itri P.A., and F.M. D'Itri, (1977); "Mercury Contamination - A Human Tragedy", John Wiley \& Sons, New York.

[11] Hindmarsh, J.T., McLetchie, O.R., Heffernan, L.P.M., Hayne, O.A., Ellenberger, H.A., McCurdy, R.F., Thiebaux, H.G., (1977); Electromyographic abnormalities in chronic environmental arsenicalism. J. Anal. Toxicol. 1, 270-276.

[12] Kori R., Saxena A. and Upadhyay N., (2006); "Groundwater quality Assessment of Mandideep Industrial area" National Seminar on Environment \& Development, Bhopal.

[13] Krishnan S.S., D.R. McLachlan, A.J. Dalton, B. Krishnan, S.A. Fenton, J.E. Harrison and T. Kruck, "Aluminium Toxicity in Humans, Essential and toxic Trace Elements in Human Health and Diseases”, Alan R. Liss., New York, 1988. 
[14] Legittimo P.C., L. Ghilardini and F. Pantani, Riv. Ital. Ig., (1985); 45, 1.

[15] Lopez desa A., 26 (207), 65 (1989).

[16] Meng, X., Korfiatis, G.P., Christodoulatos, C., Bang, S., (2001); Treatment of arsenic in Bangladesh well water using a household co-precipitation and filtration system. Water Res. 35, 2805-2810.

[17] Murrell E. Proc. - AWWA Annu. Conf., 1985, 217.

[18] Pickering, I. J.; Prince, R. C.; George, M. J.; Smith, R. D.; George, G. N.; and Salt, D. E. (2000); Reduction and Coordination of Arsenic in Indian Mustard. Plant Physiology. 126: 1171-1177.

[19] Rahman, M.M., Mandal, B.K., Roychowdhury, T., Sengupta, M.K., Chowdhury, U.K., Lodh, D., Chanda, C.R., Basu, G.K., Mukherjee, S.C., Saha, K.C., Chakraborti, D., (2003); Arsenic groundwater contamination and sufferings of people in North 24-Parganas, one of the nine arsenic affected districts of West Bengal, India. J. Environ. Sci. Health A 28, 25-59.

[20] Roychowdhury, T., 2008a. Impact of sedimentary arsenic through irrigated groundwater on soil, plant, crops and human continuum from Bengal delta: special reference to raw and cooked rice. Food Chem. Toxicol. 43, 2856-2864.

[21] Roychowdhury, T., Uchino, T., Tokunaga, H., Ando, M., (2002b); Survey of arsenic infood composites from an arsenic-affected area ofWest Bengal, India.Food Chem. Toxicol. 40, 16111621.

[22] Saravanakumar K. \&Ranjith Kumar R., (2011); "Analysis of Water Quality parameters of Groundwater near Ambattur Industrial Area, Tamil Nadu, India" Indian Journal of Science \& Technology, 4(5).

[23] Schock MR, Neff CH. (1988); Trace metal contamination from brass fittings. J Am Waterworks Assoc 80:47-56.

[24] Thienes, C., and T.J. Haley.Clinical Toxicology. 5th ed. Philadelphia: Leaand Febiger, (1972); 169.

[25] Wagner, B. J. And S.M. Gorelick. (1987). Optimal ground water quality management under parameter Uncertainty, Water Resources research Vol. 23 no. 7. Pp 1162-1174.

[26] Welch, A.H., Westjohn, D.B., Helsel, D.R., Wanty, R.B., (2000); Arsenic in groundwater of the United States: occurrence and geochemistry. Ground Water 38, 589-604.

[27] Williams, M., 2001. Arsenic in mine waters: an international study. Environ. Geol. 40, 267-278.

\footnotetext{
*Corresponding author.

E-mail address: chintagunti_venki@yahoo.com
} 